\title{
EFFECTS OF SOWING TIME AND PLANT POPULATION ON THE PRODUCTIVE POTENTIAL AND AGRONOMIC CHARACTERS IN SOY
}

\author{
EFEITO DA ÉPOCA DE SEMEADURA E POPULAÇÃO DE PLANTAS SOBRE \\ O POTENCIAL PRODUTIVO E CARACTERES AGRONÔMICOS EM SOJA
}

\begin{abstract}
Marlize Cristina Pinheiro Luiz'; Ana Paula Oliveira Nogueira²; Osvaldo Toshiyuki Hamawaki; Thúlio Pereira Mattos ${ }^{2}$; Solange Celestino Costa ${ }^{3}$; Flaviani Gabriela Pierdoná ${ }^{4}$; Raphael Lemes Hamawaki ${ }^{5}$; Cristiane Divina Lemes Hamawaki ${ }^{2}$.

1. Universidade Federal de Uberlândia, Uberlândia, MG, Brasil. marlize.pin@hotmail.com; 2. Universidade Federal de Uberlândia, Uberlândia, MG, Brasil; 3. Universidade Estadual Paulista, Jaboticabal, SP, Brasil; 4. Escola Superior de Agricultura Luiz Queiroz, Piracicaba, SP, Brasil; 5. Southern Illinois University Carbondale, SIU, Estados Unidos.
\end{abstract}

\begin{abstract}
Soy is one of the main cultivated species in the world with great economic expression and high impact on Brazilian agribusiness. The productive potential is expressed due to the genetic constitution of the cultivar and the environment in which it is exposed. The market demands for bean production require the ideal handling of the culture in order to optimize the yield potential of the plant. In this context, the handling of the culture is essential to achieve success when cultivating soy. Plant population influences the agronomic characters and consequently in the grain yield. Thus, this factor needs particular studies for each cultivar. The objective in this study was evaluating the influence of the plant population on the productive potential and agronomic characters in soy, in Uberlandia, Minas Gerais. The experiment was performed in Capim Branco Farm, which belongs to the Federal University of Uberlandia. The study was composed by 15 treatments in a $3 \times 5$ factorial scheme, constituted by three cultivars (UFUS 7415, UFUS 7401 and UFUS 6901) and five plant populations $\left(200,240,280,320\right.$ and 360 thousand plants ha $\left.{ }^{-1}\right)$. It was adopted the experimental outlining of randomized complete blocks, with five repetitions. The evaluated characters were: number of days to flowering and maturity (NDF and NDM), plant height at flowering and maturity (APF and APM), number of nodes at flowering and maturity (NNF and NNM), insertion height for the first pod (APV), total number of pods (NVT), thousand grain weight (P1000G) and productivity (PROD). It was noted that plant population didn't interfere in the soy cycle, number of nodes and thousand grain weight. The cultivars UFUS 6901, UFUS 7415 and UFUS 7401 presented better yields in populations of 240, 280 and 320 thousand plants ha ${ }^{-1}$ respectively.
\end{abstract}

KEYWORDS: Glycine max. Productivity yield. Agronomic components.

\section{INTRODUCTION}

The ascension achieved in the last decade by soy brought to the Brazilian agriculture the revolution necessary to put it in highlights and present the productive potential of the country. In the 1960's, soy didn't had economic expression nor visibility when compared to corn, coffee or sugarcane productions, for example (ALVES; TEIXEIRA FILHO; TOLLINI, 1984). However, the most highlighted factor among the ones responsible for such growth is the incessant search for genotypes which are superior and adapted to many geographic regions.

The fitotechnic works in the final stage of improvement make it easier to make recommendations to producers and collaborate to the success and development of the released genotype. The amplitude of the sowing calendar of soy is extensive and varies according to the region and the cultivar. The locations where the developed cultivar will be commercialized must be similar to the region where the pre-release tests are performed.

So, as in any agricultural activity, the productivity is affected by many variables. The definition of the plant population to be used in the tillage has one of the lowest costs to the producer, when compared to adopting technologies to elevate the productive potential of the cultivars.

The set of cultural handlings required by soy culture is diverse; the plant population combined to the spacing between the lines cause expressive changes in the tillage, such as gathering of dry matter, presence of weeds, bedding and disease dissemination (BALBINOT JUNIOR et al., 2015; VITORINO et al., 2017). There's direct influence in these variables, due to intraspecific competition for water, light and nutrients (HEIFFIG et al., 2006; BALBINOT JUNIOR et al., 2015).

The population can vary between 200 and 500 thousand plants $\mathrm{ha}^{-1}$ and due to the array and plasticity of the culture there is a possibility of 
altering the grain yield (TROGELLO; GALVÃO; SEDIYAMA, 2016). Genotypes with elevated bedding rates are recommended to populations of 200 to 250 thousand plants $\mathrm{ha}^{-1}$ and resistant genotypes, 300 thousand plants $\mathrm{ha}^{-1}$ (EMBRAPA, 2011).

Büchling et al. (2017) conducted research with the purpose of evaluating the response of nine soy genotypes in different population densities, in the southern region of the country and observed that there were no discrepant values regarding grain yield, thus, correlating this performance in the culture and plasticity of the plant.

On the other hand, Cruz et al. (2016) reported that the increment of bean productivity according to the increase of sowing density, although they utilized distinct plant spacing arrays. These authors, alongside Vasquez et al. (2014) stated that the linear increase in the bean productivity due to the sowing density referred to the number of pods per plant and weight of produced beans.

Thereby, the elevated variability of soy genotypes and release of new cultivars, it becomes a relevant matter the need to invest in studies that prioritize the fitotechnic handling of soy culture, due to the wide options of plant population.

Thus, the present study aimed to evaluate the influence of the plant population on the productive potential and agronomic characters in soy, in Uberlandia, Minas Gerais.

\section{MATERIAL AND METHODS}

The study was conducted in the experimental station Capim Branco Farm, altitude $843 \mathrm{~m}$, latitude $18^{\circ} 53^{\prime} 19^{\prime} ' \mathrm{~S}$, longitude $48^{\circ}$ $20^{\prime} 57^{\prime}$ ' $\mathrm{W}$, owned by the Federal University of Uberlandia (UFU), located in the municipality of Uberlandia, Minas Gerais.

There were evaluated three cultivars of conventional soy developed by the Program for Soy Improvement and Genetic Studies from UFU (PMEGS), UFUS 7415 (early and semideterminate growth, UFUS 7401 (early and determinate growth) and UFUS 6901 (early and indeterminate growth) and 5 plants populations $(200,240,280,320$ and 360 thousand plants ha $\left.{ }^{-1}\right)$ in factorial scheme $(3 \times 5)$, sowed in October in the 2016/2017 crop. It was adopted the experimental outlining of randomized complete blocks, with five repetitions. The portions were constituted by four $5 \mathrm{~m}$ long lines of soy plants with spacing of $0.50 \mathrm{~m}$ between them. The used area was composed by 2 central rows, eliminating $0.5 \mathrm{~m}$ from the extremities, making $4 \mathrm{~m}^{2}$ for each plot.
The experiment was implanted in an area characterized as Dystrophic Dark Red Latosol with clayey texture. A sample composed of soil was collected in the depth between 0 and $20 \mathrm{~cm}$ and was chemically analyzed. The soil preparation occurred conventionally with plowing once and harrowing twice. Afterwards, it was made the fertilizing of the sowing with $400 \mathrm{~kg} \mathrm{ha}^{-1}$ of the NPK 02-28-18 formulation.

The cultural handling, weeding, pest and disease control were performed whenever necessary, in conformity with recommendations to soy culture. (EMBRAPA, 2013).

Based on the useful area in the portion, the following agronomic characters were evaluated:

a) Number of days to flowering (NDF): corresponds to the number of days between emerging (VE) and flowering (R1) in 50\% of the used portion;

b) Number of days to maturity (NDM): corresponds to the number of days between emerging (VE) and complete maturation (R8) in $50 \%$ of the used portion;

c) Plant height at flowering (APF): distance, in centimeters, between the soil surface and the apical extremity;

d) Plant height at maturity (APM): distance, in centimeters, between the soil surface and the apical extremity;

e) Number of nodes at flowering (NNF): obtained by counting all nodes on the main haste at flowering;

f) Number of nodes at maturity (NNM): obtained by counting all nodes on the main haste at maturity;

g) Insertion height for the first pod (APV): distance, in centimeters, between the soil surface and the insertion of the first pod;

h) Total number of pods (NVT): after harvesting, it was realized an accounting on the number of pods with 1, 2, 3 and 4 beans, and afterwards it was obtained the NVT, by summing up all pods;

i) Thousand grain weight (P1000G): after grain processing the weight of one thousand grains was determined according to the methodology proposed by the Seed Analysis Rule (BRASIL, 2009);

j) Grain productivity (PROD): calculated based on the evaluation of mass of grains provided in the used area, extrapolated to $\mathrm{kg} \mathrm{ha}^{-1}$ and corrected to $13 \%$ humidity, according to the formula:

$\mathrm{PF}=\mathrm{PIx} \frac{(100-\mathrm{UI})}{(100-\mathrm{UF})}$

In which: 
PF: Corrected weight in the grains sample;

PI: Initial weight of the grains sample;

UI: Initial humidity in the grain sample;

UF: Final humidity (13\%) in the grain sample

Except for NDF, NDM and PROD, all characters were measured in five plant samples in the used portion at random.

The statistical analyses were performed in the Program for Genetics and Statistics - Programa Genes (CRUZ, 2012) and the regression analyses in the software SigmaPlot version 11.

RESULTS AND DISCUSSION
The number of days to flowering, which comprehends the vegetative cycle in a plant, is distinct between the cultivars, due to their particular sensibility to the photoperiod, which is specific in each cultivar (MATSUO; FERREIRA; SEDIYAMA, 2015). In the present study, the vegetative cycle (NDF) varied between 31 (UFUS 6901) and 37 days (UFUS 7401) and the complete cycle (NDM) from 93 (UFUS6901) to 103 days (UFUS 7415) (Table 1). It was noted that, predominantly, the vegetative cycles were similar in all plant populations, except by UFUS 6901, which presented an inferior vegetative cycle that all the others in the population of 200 thousand plants $\mathrm{ha}^{-1}$.

Table 1. Vegetative and complete cycle of three soy cultivars sowed in October in Uberlandia/MG, harvest $2016 / 2017$.

\begin{tabular}{lcccccc}
\hline \multicolumn{7}{c}{ NDF } \\
\hline \multirow{2}{*}{ Cultivar } & 200 & 240 & 280 & 320 & 360 & Mean \\
\cline { 2 - 6 } & $33.60 \mathrm{ab}$ & $35.0 \mathrm{a}$ & $34.40 \mathrm{a}$ & $32.20 \mathrm{a}$ & $34.00 \mathrm{a}$ & 34.64 \\
\hline UFUS 7415 & $31.60 \mathrm{~b}$ & $33.80 \mathrm{a}$ & $37.20 \mathrm{a}$ & $35.40 \mathrm{a}$ & $35.80 \mathrm{a}$ & 34.76 \\
UFUS 6901 & $36.20 \mathrm{a}$ & $33.20 \mathrm{a}$ & $33.40 \mathrm{a}$ & $35.60 \mathrm{a}$ & $37.40 \mathrm{a}$ & 35.16 \\
UFUS 7401 & 7.33 & & & & & \\
CV (\%) & 3.89 & & & & & \\
DMS & & & & & & \\
\hline
\end{tabular}

NDM

\begin{tabular}{lcccccc}
\hline \multirow{2}{*}{ Cultivar } & \multicolumn{6}{c}{ Plant population (one thousand plants ha ${ }^{-1}$ ) } \\
\cline { 2 - 6 } & 200 & 240 & 280 & 320 & 360 & Mean \\
\hline UFUS 7415 & 100.40 & 103.20 & 100.80 & 96.60 & 99.20 & $100.64 \mathrm{a}$ \\
UFUS 6901 & 93.80 & 97.40 & 96.60 & 95.80 & 97.00 & $96.12 \mathrm{~b}$ \\
UFUS 7401 & 101.80 & 98.00 & 101.00 & 99.00 & 102.00 & $100.36 \mathrm{a}$ \\
\hline
\end{tabular}

CV $(\%) \quad 3.02$

DMS 2.03

Means followed by letters, in vertical, do not differ statistically between themselves by the Tukey test at 5\%. NDF and NDM: Number of days to flowering and maturity, respectively.

Regarding the number of days to maturity, it was reported that the most precocious cultivar was UFUS 6901 in all plant populations, except in 240 and 320 thousand plants $\mathrm{ha}^{-1}$. UFUS 6901 stood out among the cultivars from PMEGS by its precocity (96 days) (Table 1) presenting great potential to the seed market. However, it was not possible to find a regression which could explain the biological phenomena of the cultivar during the performance of its vegetative cycle. According to Silva et al. (2015), there's a demand by cultivars with precocious cycle, because they make possible to the producer to use the area for a fast harvest or even as a mean to treat an area against diseases.
Plant height in flowering and maturity are relevant characters in studies about soy, because they are related with the bean productivity and production components (NAVARRO JUNIOR; COSTA, 2002; ORMOND et al. 2015).

Ruled by many genes, plant height is a quantitative character which is influenced by the genetic constitution of the cultivar and also by environmental effects (SEDIYAMA; TEXEIRA; BARROS, 2009). Soy plants expressed linear increase in height in function of the increment in plant population in the evaluation of flowering and maturity (APF and APM) (Figure 1), this behavior was also observed by Linzmeyer Junior et al. (2008) and Mauad et al. (2010). 

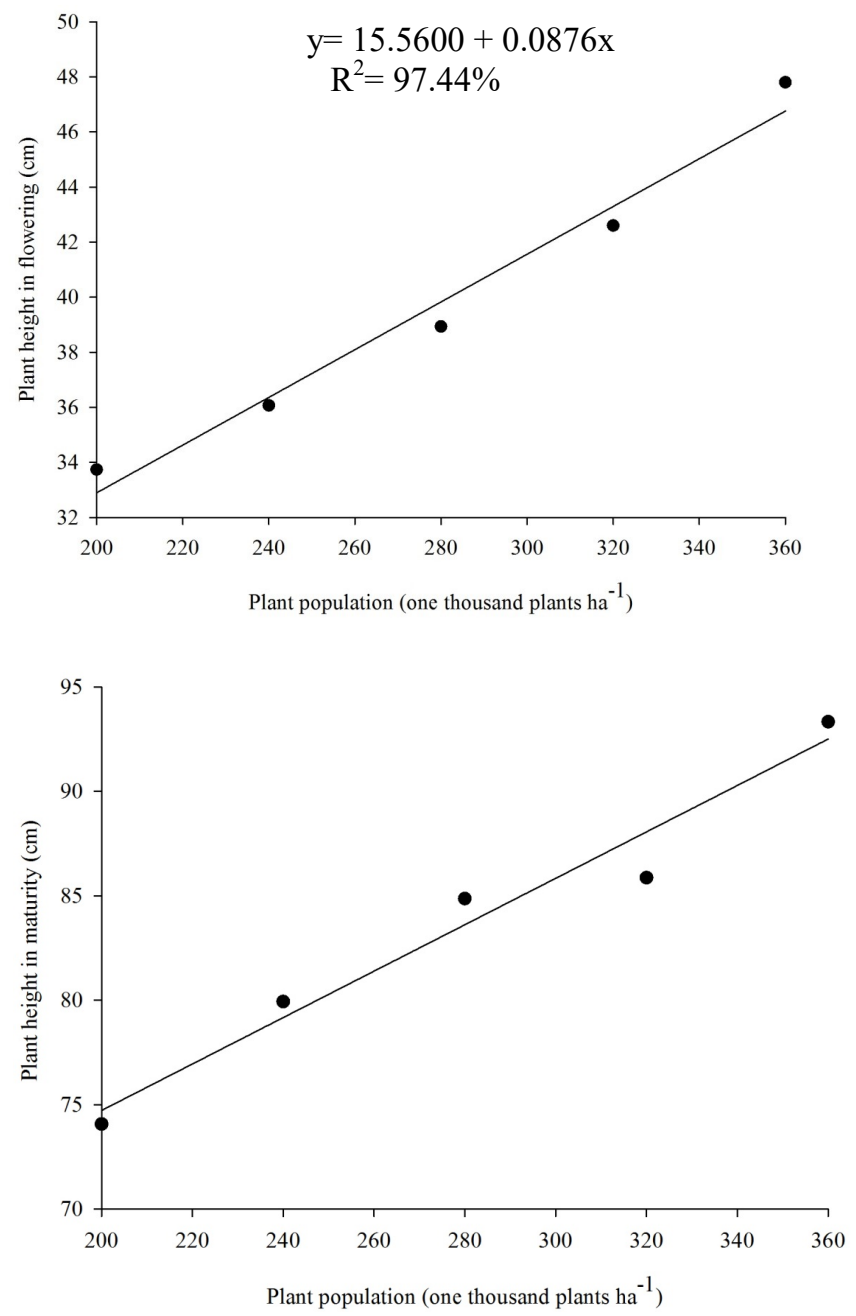

Figure 1. Plant height in flowering and maturity (APF and APM) for three soy cultivars sowed in October, in function of the plant population in the 2016/2017 harvest.

In the end of the vegetative cycle of soy, it is essential to measure plant height, once it is influenced by the growth type. Cultivar UFUS 7415, which has semideterminate growth, although presenting average height above the other cultivars in flowering $(45.37 \mathrm{~cm})$, didn't had the greater height in maturity $(74.31 \mathrm{~cm})($ Table 2$)$.

Table 2. Plant height in flowering and maturity in soy and insertion height of the first pod, sowed in October in Uberlandia/MG.

\begin{tabular}{lccc}
\hline Cultivar & APF & APM & APV \\
\hline UFUS 7415 & $45.37 \mathrm{a}$ & $74.31 \mathrm{~b}$ & $13.46 \mathrm{a}$ \\
UFUS 6901 & $37.64 \mathrm{~b}$ & $97.30 \mathrm{a}$ & $14.30 \mathrm{a}$ \\
UFUS 7401 & $36.55 \mathrm{~b}$ & $79.16 \mathrm{~b}$ & $15.76 \mathrm{a}$ \\
\hline CV (\%) & 15.79 & 11.78 & 34.95 \\
DMS & 4.28 & 6.69 & 3.35 \\
\hline
\end{tabular}

Means followed by letters, in vertical, do not differ statistically between themselves by the Tukey test at 5\%. APF and APM: Plant height at flowering and maturity, respectively; APV: Insertion height of the first pod.

Cultivar UFUS 6901 grew 2.5 times in comparison to its height in flowering and achieved the greatest final height (Table 2). This behavior can be attributed to the fact that the plant presents indeterminate growth, which happens in plants which continue to grow and produce nodes after 
flowering. Furthermore, there are reports in literature stating that plants which indeterminate growth type have a great final height, in general (EMBRAPA, 2011).

Mechanized harvest makes it easy to remove the beans from the field in the final stage of the cycle, but if performed incorrectly, it may imply in money loss to the producer, being considered tolerable a loss of up to $60 \mathrm{~kg} \mathrm{ha}^{-1}$ (SILVEIRA; CONTE, 2013). The height in the Brazilian cultivars varies from 50 to $90 \mathrm{~cm}$, which contributes to minimize loss during harvesting (SEDIYAMA; OLIVEIRA; SEDIYAMA, 2016). Cultivars from PMEGS, UFUS 7415, UFUS 6901 and UFUS 7401 obtained values near to the expected recommendation range $(74.31 \mathrm{~cm}, 97.30 \mathrm{~cm}$ and $79.16 \mathrm{~cm}$, respectively) (Table 2).

Sediyama; Teixeira; Reis (2005) and Rocha et al. (2012) mentioned that the ideal insertion height of the first pods nearly $15 \mathrm{~cm}$, but due to the technology invested in harvesters, the minimum height is $10 \mathrm{~cm}$. Cultivars from PMEGS fit the required standards (Table 2). The insertion height of the first pod (APV) didn't present discrepant alteration related to cultivars UFUS 7415, UFUS 6901 and UFUS 7401, which reached heights of 13.46, 14.30 and 15.76, respectively (Table 2). This fact can be explained by the positive correlation between APM and APV exhibited in several studies (ALMEIDA et al., 2010; NOGUEIRA et al; 2012; LEITE et al., 2015).

Costa (2013) evaluated experimental soy portions with fewer plants by meter, and it was possible to observe inferior results in plant height and insertion height of the first pod. On the other hand, Balbinot Junior et al. (2015) and Gomes et al. (2017) reported that regardless of the type of plant growth and population, there were no differences in plant height and insertion height of the first pod, when submitted to four different plant stands.

The number of nodes in soy has a direct association in the formation of the foliar canopy in plants, and consequently the volume of green matter (MARTINS et al., 2011). The number of nodes in flowering (NNF) remained the same for the three cultivars used in this study. On the other hand, cultivar UFUS 7415, in maturity (NNM) didn't remain average, reducing to 13.88 nodes (Table 3 ). Martins et al. (2011) commented that in their study realized in the municipality Santa Maria/RS in different agricultural years that, from the appearing of two consecutive nodes and on it is possible to estimate the total number of nodes on the vegetable.

Table 3. Number of nodes in flowering (R1) and reproductive (R8) in soy, sowed in October in Uberlandia.

\begin{tabular}{lcc}
\hline Cultivar & NNF & NNM \\
\hline UFUS 7415 & $9.85 \mathrm{a}$ & $13.88 \mathrm{~b}$ \\
UFUS 6901 & $9.27 \mathrm{~b}$ & $16.25 \mathrm{a}$ \\
UFUS 7401 & $9.32 \mathrm{ab}$ & $15.84 \mathrm{a}$ \\
\hline CV (\%) & 8.47 & 10.58 \\
DMS & 0.58 & 1.10 \\
\hline
\end{tabular}

Means followed by letters, in vertical, do not differ statistically between themselves by the Tukey test at $5 \%$. NNF and NNM: Number of nodes at flowering and maturity, respectively.

Formation and development of pods are decisive in soybean production, since the amount of pods depends on the number of fertilized eggs. The racemose inflorescence that soy has presents between 8 and 40 flowers and $75 \%$ of the flowers may not bear fruits, even though, the production of pods may be up to 400 per plant (NOGUEIRA et al., 2009; SEDIYAMA; OLIVEIRA; SEDIYAMA, 2016).

From another point of view, Peixoto et al. (2002) pointed out that this character (NVT) isn't satisfactory to ensure soy productivity potential, because the pod bear one to five seeds and most cultivars bore pods with two or three seeds. It was not possible to adjust a regression model for the cultivars UFUS 7415 and UFUS 7401 that could explain biologically its behavior for character NVT (Table 4 and Figure 2).

The increase in plant population for the cultivar UFUS 6901 responded inversely proportional to the number of pods per plant (NVT) (Table 4). Machado (2017) discussed that it was observed a reduction in the number of pods per plant as long as plant populations increased. According to Heiffig (2002), the number of pods per plant is the component of grain yield which is mostly influenced by plant population. These results are in accordance to those obtained by Tourino et al. (2002) and Cruz et al. (2016). 


$$
\mathrm{y}=96.68-0.2040 \mathrm{x}
$$$$
\mathrm{R}^{2}=81.68 \%
$$

Figure 2. Total pod number (NVT) of cultivar UFUS 6901, sowed in October for harvest 2016/2017.

Table 4. Number of pods, thousand grain weight and soy productivity in $\mathrm{kg} \mathrm{ha}^{-1}$, sowed in October for harvest 2016/2017.

\begin{tabular}{lcccccc}
\hline \multicolumn{7}{c}{ NVT } \\
\hline \multirow{2}{*}{ Cultivar } & 200 & 240 & 280 & 320 & 360 & Média \\
\cline { 2 - 6 } & $50.60 \mathrm{a}$ & $62.24 \mathrm{a}$ & $42.48 \mathrm{a}$ & $54.51 \mathrm{a}$ & $41.24 \mathrm{a}$ & 50.21 \\
\hline UFUS 7415 & $54.08 \mathrm{a}$ & $55.80 \mathrm{a}$ & $30.72 \mathrm{a}$ & $32.12 \mathrm{~b}$ & $24.90 \mathrm{a}$ & 39.52 \\
UFUS 6901 & $37.56 \mathrm{a}$ & $26.36 \mathrm{~b}$ & $35.68 \mathrm{a}$ & $37.04 \mathrm{ab}$ & $30.64 \mathrm{a}$ & 33.45 \\
UFUS 7401 & 28.24 & & & & \\
CV (\%) & 17.66 & & & & \\
DMS & & & & & \\
\hline
\end{tabular}

P1000G

\begin{tabular}{lcccccc}
\hline \multirow{2}{*}{ Cultivar } & \multicolumn{7}{c}{ Plant population (one thousand plants ha ${ }^{-1}$ ) } \\
\cline { 2 - 7 } & 200 & 240 & 280 & 320 & 360 & Média \\
\hline UFUS 7415 & 165.00 & 175.50 & 172.50 & 173.50 & 173.75 & $172.05 \mathrm{a}$ \\
UFUS 6901 & 173.50 & 174.75 & 176.00 & 173.75 & 179.75 & $175.55 \mathrm{a}$ \\
UFUS 7401 & 174.75 & 172.75 & 170.25 & 171.00 & 177.00 & $173.15 \mathrm{a}$ \\
\hline CV (\%) & 4.68 & & & & \\
DMS: & 5.53 & \multicolumn{7}{c}{} & & \\
\hline
\end{tabular}

PROD

\begin{tabular}{lcccccc}
\hline \multirow{2}{*}{ Cultivar } & \multicolumn{7}{c}{ Plant population (one thousand plants ha ${ }^{-1}$ ) } \\
\cline { 2 - 7 } & \multicolumn{1}{c}{200} & 240 & 280 & 320 & 360 & Média \\
\hline UFUS 7415 & $2816.40 \mathrm{a}$ & $3067.00 \mathrm{a}$ & $3715.51 \mathrm{a}$ & $3345.50 \mathrm{a}$ & $3686.46 \mathrm{a}$ & 3326.18 \\
UFUS 6901 & $2990.59 \mathrm{a}$ & $3166.36 \mathrm{a}$ & $2176.99 \mathrm{~b}$ & $2295.82 \mathrm{~b}$ & $2389.98 \mathrm{~b}$ & 2603.95 \\
UFUS 7401 & $2143.18 \mathrm{a}$ & $2279.34 \mathrm{a}$ & $2717.58 \mathrm{~b}$ & $3533.30 \mathrm{a}$ & $3157.50 \mathrm{ab}$ & 2766.18 \\
\hline CV (\%) & 22.43 & & & & \\
DMS & 990.73 & & & & & \\
\hline
\end{tabular}

Means followed by letters, in vertical, do not differ statistically between themselves by the Tukey test at 5\%. NVT: Total pod number; P1000G: thousand grain weight; PROD: Grain productivity. 
It is known that the number of pods ant the number of grains are defined by the time of flowering on soy (KNEBEL et al., 2006). Lima et al. (2009) stated that the photoperiod interfered in the amount of flowers in the flowering period, affecting the number of pods, diverging from the results of the present work, in which both environments presented similar means. Furthermore, egg fertilization problems or lack of nutrients destined to fill the beans are reflected in empty pods (LIMA et al., 2009).

The definition of culture productivity is related to production components of the plants, being these: number of pods, number of seeds per pod and grain weight (DALCHIAVON; CARVALHO, 2012). Bezerra et al. (2016) clarified that seeds with greater mass in ideal conditions became better nurtured plants, being consequently more productive and Fonseca et al. (2016) affirmed that the weight of one thousand seeds is relevant to calculate sowing density and its uniform distribution. Sediyama; Oliveira; Sediyama (2016) pointed out that the average seed weight of soy for industrial purposes may vary between 12 and $20 \mathrm{~g}$ per 100 seeds.

LUIZ, M. C. P. et al.

The mass of soy seeds is originated from photosynthetic activity and photoassimilated translocation to grains during the filling period, which indicates that different plant populations do not generate variation difference in the thousand grain weight (P1000G) (Table 4) (KNEBEL et al., 2006). Similar results were achieved by Procópio et al. (2013) and Procópio et al. (2014) when testing plant populations that also didn't found differences in seed mass.

Grain productivity is the most desired character in field researches and its result depends on a variety of genetic, environmental and handling factors, thus, researches are a necessity for correct and efficient recommendations to soy plant populations.

Cultivar UFUS 7401 incremented linearly its production with the elevation of plant population (Figure 3). Seus (2011) working with population density of soy cultivars in meadow soil obtained results which were similar to those in this work and Gomes et al. (2017) in Boa Vista/RR evaluated soy productivity in four population densities $(10,14,18$ and 22 plants $\mathrm{m}^{-1}$ ), in Embrapa Experimental Fields, and reported that the increase in plants per row reflected in the increase of grain productivity.

- $y=-899.4869+25.9917 x-0.0374 x^{2}$

$\mathrm{R}^{2}=71.17 \%$

○ $y=-23110.05+312.388 x-1.2052 x^{2}$ $+0.0015 \mathrm{x}^{3}$

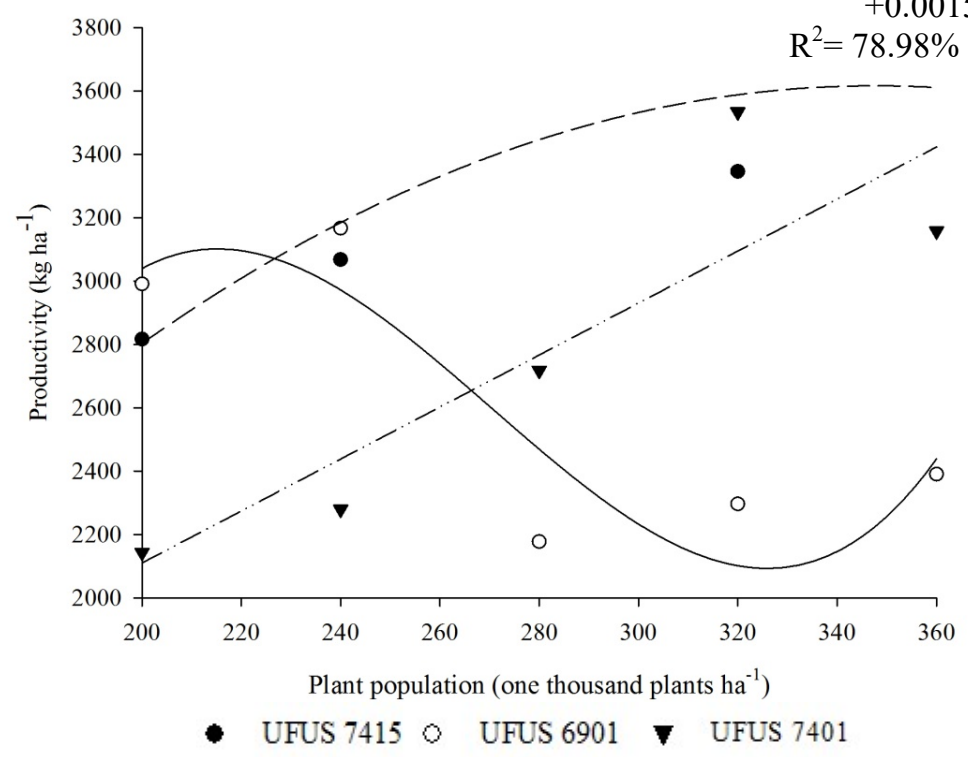

Figure 3. Soy productivity $\left(\mathrm{kg} \mathrm{ha}^{-1}\right)$ of cultivars from PMEGS sowed in Uberlandia.

In the population of 320 plants $^{-1}$ cultivars UFUS 7415 and UFUS 7401 obtained grain yield superior to $3300 \mathrm{~kg} \mathrm{ha}^{-1}$ (Table 4). Although, the population of 280 thousand plants $\mathrm{ha}^{-1}$ favored the grain yield for cultivar UFUS 7415 (3715.51 ha $\left.{ }^{-1}\right)$, offering to the seed market a viable cost-effective option by adopting smaller plant populations. Giraldi (2016) and Büchling et al. (2017) observed 
in their field studies a productivity response similar to the one in the present work.

Andrade et al. (2016) evaluated the development of soy cultivated in conventional and crossed planting in different population densities and confirmed that the treatments behaved in a homogeneous fashion towards the stipulated factors, without reporting increments in yield with the increase of plant stands. Balbinot Junior et al. (2015) also didn't report effects in grain productivity, when submitted to two sowing densities in soy, in Londrina/PR. This behavior may be explained by the plasticity of soy culture, keeping productivity uniform towards discrepant agricultural managements (RITCHIE, 1996; BALBINOT JUNIOR et al., 2015).

The state of Minas Gerais achieved the mark of $3480 \mathrm{~kg} \mathrm{ha}^{-1}$ of soy in the harvest 2016/2017, while the national productivity obtained $3364 \mathrm{~kg} \mathrm{ha}^{-1}$ (CONAB, 2018). Such yields are close to the cultivars from the improvement program from UFU. Thus, the performance of conventional soy cultivars, when sowed in October, presented the ability the cultivars have to compete in the agricultural market.

\section{CONCLUSIONS}

Plant population influenced in agronomic characters and productivity potential of soy cultivars, except for the populations of 200 and 240 thousand plants ha ${ }^{-1}$ didn't influence in the grain yield of cultivars UFUS 7415, UFUS 7401 and UFUS 6901.

The population of 280 thousand plants $\mathrm{ha}^{-1}$ provided high grain productivity for cultivar UFUS 7415.

UFUS 7401 obtained its best yield in the population of 320 thousand plants ha ${ }^{-1}$.

The cultivar UFUS 6901 reached its highest yield in the population of 240 thousand plants $\mathrm{ha}^{-1}$.

\section{ACKNOWLEDGMENT}

To the Coordination of Personal Improvement in Higher Education (CAPES) for conceding a scholarship.

RESUMO: A soja é uma das principais espécies cultivadas no mundo, com grande expressão econômica e alto impacto no agronegócio brasileiro. O potencial produtivo é expresso devido à constituição genética da cultivar e ao ambiente em que está exposta. As demandas do mercado para a produção do grão requerem o manuseio ideal da cultura, a fim de otimizar o potencial de rendimento da planta. Nesse contexto, o manejo da cultura é essencial para obter sucesso no cultivo da soja. A população de plantas influencia os caracteres agronômicos e, consequentemente, no rendimento de grãos. Assim, esse fator necessita de estudos específicos para cada cultivar. O objetivo deste estudo foi avaliar a influência da população de plantas no potencial produtivo e nos caracteres agronômicos da soja, em Uberlândia, Minas Gerais. O experimento foi realizado na Fazenda Capim Branco, pertencente à Universidade Federal de Uberlândia. O estudo foi composto por 15 tratamentos em esquema fatorial 3x5, constituído por três cultivares (UFUS 7415, UFUS 7401 e UFUS 6901) e cinco populações de plantas $\left(200,240,280,320\right.$ e 360 mil plantas ha $\left.^{-1}\right)$. Foi adotado o delineamento experimental de blocos completos casualizados, com cinco repetições. Os caracteres avaliados foram: número de dias para o florescimento e maturidade (NDF e NDM), altura da planta no florescimento e maturidade (APF e APM), número de nós no florescimento e maturidade (NNF e NNM), altura de inserção da primeira vagem (APV), número total de vagens (NVT), peso de mil grãos (P1000G) e produtividade (PROD). Observou-se que a população de plantas não interferiu no ciclo da soja, número de nós e peso de mil grãos. As cultivares UFUS 6901, UFUS 7415 e UFUS 7401 apresentaram melhores rendimentos nas populações de 240, 280 e 320 mil plantas $\mathrm{ha}^{-1}$, respectivamente.

PALAVRAS-CHAVE: Glycine max. Rendimento de produtividaade. Componentes agronômicos.

\section{REFERENCES}

ALMEIDA, R. D.; PELUZIO, J. M.; AFFERRI, F. S. Correlações fenotípicas, genotípicas e ambientais em soja cultivada sob condições várzea irrigada, sul do Tocantins. Bioscience Journal. Universidade Federal de Uberlândia, Uberlândia, v. 26, n. 1, p. 95-99, 2010. https://doi.org/10.1590/S1806-66902011000100014 
ALVES, E.; TEIXEIRA FILHO, A.; TOLLINI, H. Demographicaspectsofagriculturaldevelopment: Brazil, 1950-74. In: YEGANIANTZ, L. (Ed.). Brazilian agriculture and agricultural research. Brasília: Embrapa, 1984. p. 9-60.

ANDRADE, F. R., NÓBREGA, J. C. A., ZUFFO, A. M., JUNIOR, V. P. M., RAMBO, T. P., dos Santos, A. S. Características agronômicas e produtivas da soja cultivada em plantio convencional e cruzado. Revista de Agricultura, Piracicaba, v. 91, n. 1, p. 81-91, 2016.

BALBINOT JUNIOR, A. A.; PROCÓPIO, S. O.; DEBIASI, H; FRANCHINI, J. C.; PANISON, F. Semeadura cruzada em cultivares de soja com tipo de crescimento determinado. Semina: Ciência Agrárias, Londrina, v.36, p. 1215- 1226, 2015. https://doi.org/10.5433/1679-0359.2015v36n3p1215

BEZERRA, A. R. G.; SOARES, M. M.; SEDIYAMA, T. Em: Tamanho e vigor da semente. SEDIYAMA, T. (Ed.). Produtividade de soja. Mecenas: Londrina, 2016. p. 142-155.

BRASIL. Ministério da Agricultura, Pecuária e Abastecimento. Secretaria de Defesa Agropecuária. Regras para análise de sementes. Brasília: MAPA/ACS, 2009. 399 p.

BÜCHLING, C.; DE OLIVEIRA NETO, A. M.; GUERRA, N.; BOTTEGA, E. Uso da plasticidade morfológica como estratégia para a redução da população de plantas em cultivares de soja. Agrarian, Grande Dourados, v. 10, n. 35, p. 22-30, 2017. https://doi.org/10.30612/agrarian.v10i35.3931

COMPANHIA NACIONAL DE ABASTECIMENTO CONAB. Acompanhamento da safra brasileira: grãos: quarto levantamento, janeiro, 2018. Brasília: CONAB, 2018. Disponível em:

$<$ http://www.conab.gov.br>. Acesso em: 12 jan. 2018.

COSTA, E. D. Arranjo de plantas, características agronômicas e produtividade de soja. 2013, 60 f. Dissertação (Mestrado em Agronomia) - Curso de Pós-Graduação em Agronomia, Universidade Estadual Paulista "Júlio de Mesquita Filho. 2013.

CRUZ, C. D.; REGAZZI, A. J.; CARNEIRO, P. C. S. Modelos biométricos aplicados ao melhoramento genético. v. 1, 4. ed. Viçosa: UFV, 2012. 514 p.

CRUZ, S. C. S.; SENA-JUNIOR, D. G.; SANTOS, D. M. A.; LUNEZZO, L. O.; MACHADO, C. G. Cultivo de soja sob diferentes densidades de semeadura e arranjos espaciais. Revista de Agricultura Neotropical, Cassilândia, v. 3, n. 1, p. 1-6, 2016. https://doi.org/10.32404/rean.v3i1.431

DALCHIAVON, F. C.; CARVALHO, M. P. Correlação linear e espacial dos componentes de produção e produtividade da soja. Semina: Ciências Agrárias, Londrina, v. 33, n. 2, p. 541-552, 2012.

https://doi.org/10.5433/1679-0359.2012v33n2p541

EMPRESA BRASILEIRA DE PESQUISA AGROPECUÁRIA - EMBRAPA. Tecnologias de Produção de Soja- Região central do Brasil, 2012 e 2013. Londrina: EMBRAPA, 2011, p. 264.

EMPRESA BRASILEIRA DE PESQUISA AGROPECUÁRIA - EMBRAPA. Tecnologias de Produção de Soja- Região central do Brasil, 2013 e 2014. Londrina: EMBRAPA, 2013, p. 265.

FONSECA, J.; GOULART, R. Z.; CARDOSO, P.; CHAIBEN, M., PYDD, E. B. Germinação e peso de mil sementes de soja sob diferentes tipos de manejo de solo. Anais do Salão Internacional de Ensino, Pesquisa e Extensão, v. 7, n. 2, 2016.

GIRALDI, F. Produtividade de soja em diferentes populações de plantas e sítios específicos de manejo em semeadura após a época indicada. 2016, 71 f. Dissertação (Mestrado em Agricultura de Precisão) - Programa de Pós-Graduação em Agricultura de Precisão, Universidade Federal de Santa Maria, Santa Maria, 2016. 
GOMES, H. D. S.; SMIDERLE, O. J.; de MENEZES, P. H. S.; GIANLUPPI, V.; MARQUES, C. Características agronômicas na produtividade da soja em diferentes densidades de plantas. In: Embrapa Roraima-Artigo em anais de congresso (ALICE). In: CONGRESSO BRASILEIRO DE AGRONOMIA, 30, 2017, Fortaleza, Anais... Segurança hídrica: um desafio para os engenheiros agrônomos do Brasil: AEAC: CONFAEAB, 2017.

HEIFFIG, L. S. Plasticidade da cultura de soja (Glycinemax (L.) Merrill) em diferentes arranjos espaciais. 2002, 80 f. Dissertação (Mestrado em Agronomia) - Curso de Pós-Graduação em Agronomia, Escola Superior de Agricultura Luiz de Queiroz, Piracicaba, 2002.

HEIFFIG, L. S.; CÂMARA, G. M. S.; MARQUES, L. A.; PEDROSO, D. B.; PIEDADE, S. M. S. Fechamento e índice de área foliar da cultura da soja em diferentes arranjos espaciais. Bragantia, Campinas, v. 65, n. 2, p. 285-295, 2006. https://doi.org/10.1590/S0006-87052006000200010

KNEBEL, J. L.; GUIMARÃES, V. F.; ANDREOTTI, M.; STANGARLIN, J. R. Influência do espaçamento e população de plantas sobre doenças de final de ciclo e oídio e caracteres agronômicos em soja. Acta Scientiarum. Agronomy, Maringá, v. 28, n. 3, 2006. https://doi.org/10.4025/actasciagron.v28i3.962

LEITE, W. S.; PAVA, B. E.; MATOS FILHO, C. H. A.; FEITOSA; F. S.; OLIVEIRA, C. B. Estimativas de parâmetros genéticos e correlações entre caracteres agronômicos em genótipos de soja. Nativa, Sinop, v. 03, n. 04, p. 241-245, 2015. https://doi.org/10.14583/2318-7670.v03n04a03

LIMA, E. V., CRUSCIOL, C. A. C., CAVARIANI, C.; NAKAGAWA, J. Agronomic traits, yield and physiological quality of " safrinha" (off-season) soybean under no till as a function of plant cover and surface liming. Revista Brasileira de Sementes, v. 31, n. 1, p. 69-80, 2009. https://doi.org/10.1590/S010131222009000100008

LINZMEYER JUNIOR, R., GUIMARÃES, V. F., DOS SANTOS, D.; BENCKE, M. H. Influência de retardante vegetal e densidades de plantas sobre o crescimento, acamamento e produtividade da soja. Acta Scientiarum. Agronomy, Maringá, v. 30, n. 3, 2008. https://doi.org/10.4025/actasciagron.v30i3.3547

MACHADO, B. Q. V. Diversidade genética em soja com diferentes níveis de resistência ao sclerotinia sclerotiorum, correlações, análise de trilha e população de plantas. 2017, 103 f. Dissertação (Mestrado em Agronomia) - Curso de Pós-Graduação em Agronomia, Universidade Federal de Uberlândia. Uberlândia, 2017.

MARTINS, J. D.; ZWICK RADONS, S.; STRECK, N. A.; KNIES, A. E.; CARLESSO, R. Plastocrono e número final de nós de cultivares de soja em função da época de semeadura. Ciência Rural, Santa Maria, v. 41, n. 6, 2011. https://doi.org/10.1590/S0103-84782011005000064

MATSUO, É.; FERREIRA, S. C.; SEDIYAMA, T. Botânica e Fenologia. In: SEDIYAMA, T.; SILVA, F.; BORÉM, A. (Ed.). Soja: do plantio à colheita. UFV, Viçosa, 2015, p. 27-53.

MAUAD, M.; SILVA, T. L. B.; NETO, A. I. A.; ABREU, V. G. Influência da densidade de semeadura sobre características agronômicas na cultura da soja. Agrarian, Grande Dourados, v. 3, n. 9, p. 175-181, 2010.

NAVARRO JÚNIOR, H. M.; COSTA, J. A. Contribuição relativa dos componentes do rendimento para produção de grãos em soja. Pesquisa Agropecuária Brasileira, Brasília, v.37, n.3, p.269-274, 2002. https://doi.org/10.1590/S0100-204X2002000300006

NOGUEIRA, A. P. O.; SEDIYAMA, T.; BARROS, H. B.; TEIXEIRA, R. C. Morfologia, crescimento e desenvolvimento. In: SEDIYAMA, T. (Ed). Tecnologias de produção e usos da soja. Londrina: Mecenas, 2009, p. 7-16. 
NOGUEIRA, A. P. O.; SEDIYAMA, T.; DE SOUSA, L. B.; HAMAWAKI, O. T.; CRUZ, C. D.; PEREIRA, D. G.; MATSUO, É. Análise de trilha e correlações entre caracteres em soja cultivada em duas épocas de semeadura. Bioscience Journal, Uberlândia, v. 28, n. 6, 2012.

ORMOND, A. T. S.; VOLTARELLI, M. A.; PAIXÃO, C. S. S., GÍRIO, L. A. S.; ZERBATO, C.; SILVA, R. P. Características agronômicas da soja em semeadura convencional e cruzada. Revista Agro@mbiente Online, Roraima, v. 9, n. 4, p. 414-422, 2015. https://doi.org/10.18227/1982-8470ragro.v9i4.2706

PEIXOTO, C. P.; PEIXOTO, M.; FREITAS, S. P.; SANTOS, A. R.; SILVA, V. Matéria seca, área foliar e rendimento de grãos em cultivares de soja sob déficit hídrico em diferentes fases fenológicas. In: Congresso Brasileiro de Engenharia Agrícola, 31., 2002, Salvador. Anais...Salvador: Sociedade Brasileira de Engenharia Agrícola, 2002. 1 CD ROM.

PROCÓPIO, S. O.; BALBINOT JUNIOR, A. A.; DEBIASI, H.; FRANCHINI, J. C.; PANISON, F. Plantio cruzado na cultura da soja utilizando uma cultivar de hábito de crescimento indeterminado. Revista de Ciências Agrárias/Amazonian Journal of Agricultural and Environmental Sciences, v.56, n. 4, p. 319-325, 2013. https://doi.org/10.4322/rca.2013.048

PROCÓPIO, S. O., BALBINOT JUNIOR, A. A., DEBIASI, H., FRANCHINI, J. C.; PANISON, F. Semeadura em fileira dupla e espaçamento reduzido na cultura da soja. Revista Agro@mbiente On-line, Roraima, v. 8, p. 212-221, 2014. https://doi.org/10.18227/1982-8470ragro.v8i2.1469

RITCHIE, S. W. How a soy bean plant develops. Ames: Iowa State University of Science and Technology Cooperative Extension Service, 1982. Adaptado por Yorinori, J. T. 1996. Reunião de pesquisa de soja da região sul, p. 135, 2007.

ROCHA, R. S., SILVA, J. A. L., NEVES, J. A., SEDIYAMA, T., TEIXEIRA, C. R. Desempenho agronômico de variedades e linhagens de soja em condições de baixa latitude em Teresina-PI. Revista Ciência Agronômica, Fortaleza, v. 43, n. 1, p. 154-162, 2012. https://doi.org/10.1590/S1806-66902012000100019

SEDIYAMA, T.; TEIXEIRA, R. C.; REIS, M. S. Melhoramento da Soja. In: BORÉM, A. (Ed.).

Melhoramento de espécies cultivadas. Viçosa: UFV, 2005. p. 553-604.

SEDIYAMA, T.; TEIXEIRA, R. C.; BARROS, H. B. Origem, evolução e importância econômica. In: SEDIYAMA, T. (Ed.). Tecnologias de produção e usos da soja. Londrina: Editora Mecenas, 2009. p. 1-5.

SEDIYMA VERIFICAR NOME DO AUTOR, T.; OLIVEIRA, R. C. T.; SEDIYAMA, H. A. A soja. In: SEDIYAMA, T. (Ed.). Produtividade da Soja. Mecenas: Londrina, 2016. p. 11-18.

SEUS, R. Densidade populacional de cultivares de soja em solo de várzea: desempenho da cultura e qualidade fisiológica das sementes. 2011, 77 f. Dissertação (Mestrado em Ciências) - Programa de PósGraduação em Ciência e Tecnologia de Sementes, Universidade Federal de Pelotas, Pelotas, 2011.

SILVA, A. F.; SEDIYAMA, T.; BORÉM, A.; SILVA, F. C. S. Cultivares. In: SEDIYAMA, T.; SILVA, F.; BORÉM, A. (Ed). Soja: do plantio à colheita. Viçosa: UFV. 2015. p. 149-67.

SILVEIRA, J. M.; CONTE, O. Determinação de perdas na colheita de soja: copo medidor da Embrapa. Embrapa Soja-Fôlder/Folheto/Cartilha (INFOTECA-E), 2013.

TOURINO, M. C. C.; REZENDE, P. M.; SALVADOR, N. Espaçamento, densidade e uniformidade de semeadura na produtividade e características agronômicas da soja. Pesquisa Agropecuária Brasileira, Brasília, v.37, p. 1071-1077, 2002. https://doi.org/10.1590/S0100-204X2002000800004

TROGElLO, E.; GALVÃO, J. C. C.; SEDIYAMA, T. Distribuição espacial de plantas. In: SEDIYAMA, T. (Ed.). Produtividade da Soja. Mecenas: Londrina, 2016. p. 156-169. 
VAZQUEZ, G. H.; PERES, A. R.; TARSITANO, M. A. A. Redução na população de plantas de soja e o retorno econômico na produção de grãos. Científica, Jaboticabal, v. 42, n. 2, p. 108-117, 2014. https://doi.org/10.15361/1984-5529.2014v42n2p108-117 .

VITORINO, H. D. S., SILVA JUNIOR, A. C. D., GONÇALVES, C. G.; MARTINS, D. Interference of a weed community in the soybean crop in functions of sowing spacing. Revista Ciência Agronômica, Fortaleza, v. 48, n. 4, p. 605-613, 2017. https://doi.org/10.5935/1806-6690.20170070 